FACTA UNIVERSITATIS

Series: Teaching, Learning and Teacher Education Vol. 1, № 2, 2017, pp. 113 - 126

https://doi.org/10.22190/FUTLTE1702113S

Original research paper

\title{
FUTURE I IN THE SPEECH OF THE VRANJE'S CHILDREN IN PRESCHOOL AND PRIMARY SCHOOL
}

\author{
UDC 37.016:81-053.4; 81'366.584.2-053.4
}

\section{Dragana Stanković}

\author{
Pedagogical Faculty in Vranje, University of Niš, Serbia
}

\begin{abstract}
The paper presents the results of an analysis of the usage of future tenses forms in the speech of the Vranje's children of preschool and primary school age. In this regard, all forms of future tense are used by the examinees, and then by calculating the frequency index $(I F)$ the frequency of usage of the dialect futures structure and the dependence of the usage of this structure on non-linguistic factors - the age of pupils, sex, education of both parents, places of residence, attending kindergarten / school. The sample covered 40 examinees, children of pre-school and primary school age, different sex, parents education and place of residence. The obtained results indicate the usage of three different constructions in the service of Futures I, whereby the dialect future structure is the most frequent and resistant to the influence of the language standard. So, the influence of non-linguistic factors on the usage of the dialect future form is visible, but not great. As a result, age and gender have no influence. The obtained results can contribute to the improvement of the processing of futures in the teaching of the Serbian language, which is particular importance for teaching in the pronounced dialectical area such as the Prizren-South Moravian region, to which the Vranje's speech belongs to.
\end{abstract}

Key words: children's speech, futur I, frequency, non-linguistic factors.

\section{THEORETICAL CONSIDERATIONS}

Through the education system, the mass media of communication, the mobility of the population and various contacts, the number of standard linguistic features in the dialects increases. Social changes put the dialectologists ahead of a number of new issues, impose a new subject of research, changes in approaches and methods. All changes in the

Received October 10, 2017/Accepted January 10, 2017

Corresponding author: Dragana Stanković

Pedagogical Faculty in Vranje, University of Niš, Partizanska 14, 17500 Vranje, Serbia

Phone: +381 17 431-960 •E-mail: gagat79@gmail.com

The paper presents a part of the research carried out during the preparation of the doctoral dissertation entitled

The Speech of the Vranje's Children Preschool and School Age - sociolinguistic approach. 
language are most evident in the speech of the youngest population of a linguistic area. That is why children's speech gives a dialectologist a lot of research material - how the speech is realigned, changed, how it makes compromise with standard language forms, in which grammatical categories of the dialectic system tolerates the speech of the youngest, to what extent the standard language disrupts the dialectic system and which dialectical qualities are first to be changed, which ones persistently remain, what kind of speech variant develops among school children, whether they have developed a kind of coine, whether it is and how much speech is close to the standard language.

The assimilation of the speech at the youngest takes place in coexistence with numerous factors. In a sociolinguistic research, age is an important factor that determines linguistic differences. The speech of the child differs from the speech of the parents, and even more than the speech of the grandparents. In this regard, age is the most important indicator of language change, and therefore a very important variable in language research. The research of the speech of different age groups determines the changes in apparent time, as well (Labov, 1976). The key question is, which group can be defined as an age group. The researchers most often take a range of twenty years of age. Dunja Jutronić-Tihomirović performs the research in the speech of three generations: 18-30, 30-50 and 50-70 years (Jutronić-Tihomirović, 1988-1989). Ljubiša Rajić (1980), based on the age, forms three groups: the first group consists 10 examinees older than 50, the second group consists 10 examinees between 30 and 50, and the third group consists 10 examinees under the age of 30. In Novi Sad Corpus of colloquial language, children (1-7 years old), adolescents and adults are included (Savić, 1999). Dušan Jović (1979) monitors certain linguistic phenomena in the speech of three generations, younger, middle-aged and the oldest, and concludes that the youngest generation is approaching to norms, the eldest the least, and the middle-aged one has the least stable linguistic norm. In the process of language adaptation to the urban environment, changes are visible at the generation level. Analyzing the origin and features of Belgrade's speech, Miloš Moskovljević (1921) notes that when arriving in urban Belgrade environment, parents more or less keep treasuring the characteristics of their local speech, as long as their children speak with one common speech, in which all the differences have been leveled, and a new type of speech is obtained. It is a lively and vigorous speech, which has its own natural development and its laws. Through the anecdote of the family that has been living in Belgrade for 11 years, Dušan Jović (1976) shows that dialectical, standard and urban elements are crossed, wherein three generations in that family, grandmother, mother and daughter show three different language behaviors. Jovan Jerković (1992) conducted a conversation with two generations of immigrants in Becej and their descendants who were born in Becej and concluded that the immigrants value a certain feature of their speech, while their descendants were completely linguistically adapted to a new environment. It is obvious that researchers mainly analyze the speech of three age groups, whereby the speech of the youngest population, children under 18 , is the least researched. Thereby, the general conclusion of the above mentioned researches is that the language of the youngest examinees is the closest to the linguistic norm.

The speech of the younger population has drawn the attention of the pedagogue more than the dialectologist. The speech of children of pre-school and school age up to 18 years is mainly studied from the aspect of developmental speech (adoption of voices, forming words and sentences, etc.), language competences (knowledge of language norm), spoken and lexical culture. Children's speech is a rarity in our dialectological research. Marina Janjić (2005), analyzing the usage of cases in 120 oral and written exercises of students of the first and fourth grades and all upper grades in two primary 
school in Vranje, found 351 sentences with cases' mistakes. More than half of the mistakes made, Janjić points out, refers to the wrong usage of the accusative and locative in the function of the preposition of place, more often the locative than the accusative. Jovan Mihajlovic (2008) in the speech of the youth of the Municipality of Strpce opens the following questions: what is the influence of the standard language on a dialect (which students use outside of the school), how much the norm of standard language is valued on Serbian language classes, and how much on other school subjects, and has the Albanian language influence, has the language of migrants influence on the Iekavian pronunciation. The paper presents the material (to which the author came by recording the pupils' speeches at classes), but the analysis of this material is missing. Žarko Bošnjaković (2009) analyzes the relationship between standard linguistic and dialectical morphological forms in the speech of students of the fifth and eighth grade of three rural and two city schools in central and southeastern Banat. Marina Janjić (2011) researches the speech of the secondary school population of Vranje's students on a dialect - standard language - student language relation, examining their attitudes about dialect, standard language and Anglicism, and analyzing the slang in their informal, colloquial speech. Jordana Marković (2012) notices standard and dialectical forms in children's speech between the age of four and six. Radmila Žugić (2013), on the Corpus of fifty-eight written works of students from the Prizren-Timok's dialect area, considers the nonstandard usage of case forms. On that occasion, she identified two types of inadequate usage of the case - the usage of preschool case's syntagms with a general case function of the corresponding standard form of the case and the non-standard usage of the case, which involves mixing and replacing the case forms. Comparing the results of this research with the results obtained by Marina Janjić in 2005, Žugić concludes that students in primary school make less mistakes in usage of cases than university students. Such conclusion imposes the question why students regress in overmastering the usage of cases. The crucial reason of this state the author sees as the great linguistic distance between Prizren-Timok's speeches and the Serbian standard language, which "makes the acceptance of the standard language difficult and long" (Žugić, 2013: 526).

The research of the speech of children of school age implies the question of teaching languages and dialects. The overcoming of the standard Serbian language in a prominent dialectical area, such as Prizren-Timok's, is largely hampered by the influence of local speech. Therefore, the need for applying specific methodical procedures in the teaching of the Serbian language is imposed. The significance of the local speech of students in the acceptance of the language standard, it is necessary that in teaching of the mother tongue start from the local speech of the students, and in this regard, the curriculum should be adapted to the speech area and so-called differential grammar should be made as many linguists and methodologists indicate (Nikolić, 1956; Vrećić, 1975, 1977; Dešić, 1981; Nikolić, 1998; Ćupić, 2001; Radić, 2008). In several of his works, M. Janjić deals with the teaching of a standard and accentual system of the standard language, starting from the local speech of students in mastering the language rules (Janjić 2004, 2005a, 2005b, 2016). Javorka's Marinković and Jovan's Janjić (2009) Differential grammar is the first textbook that starts from dialectical differences in mastering the language standard. Theoretical and methodological standpoints on the adoption of language standards in the dialect area were also presented in the monograph "Teaching Serbian Language in the Dialectical Area"by authors Stana Smiljković, Radmila Žugić and Slavka Stojanović (Smiljković, Žugić \& Stojanović, 2009).

Since the study of children's speech is a rarity in dialectological research on the territory of Serbia, the research of the Future I in the speech of Vranje's children of preschool and 
primary school age seems justified and important both for the teaching of the Serbian language in a pronounced dialectical area and for the examination of the status of a futuristic structure in Serbian language.

\section{METHOdOLOGICAL FRAMEWORK OF RESEARCH}

The aim of the research was to determine all forms of Futures I and to show its variations, and then to determine to which extent the dialectic forms are present and how much they are conditioned by non-linguistic factors. For the analysis of this language variable, we decided on the basis of the conducted research, because the dialectic form of Futures I showed the highest resistance to the influence of the standard language ${ }^{1}$. Under the language variable, we mean ,a unit with at least two variant forms, which choice depends on different factors" (Kristal, 1987: 32).

Within the framework of such aim, we determined the following: variable forms of Future I; frequency of usage of dialectic forms of Future I and frequency of usage of dialectic forms of Future I and depending on non-language variables - students age, sex, education of both parents, place of residence, attendance at kindergarten / school. The speech of 40 examinees of different age, sex, place of residence, education of parents was analyzed. As the subject of the survey is urban speech, examinees are children who were born and live in Vranje and whose parents were born and live in Vranje. According to their age, the examinees were divided into three groups - children of pre-school age (16 rexaminees), school age children from first to fourth grade (12 examinees) and school age children from fifth to eighth grade (12 examinees). Within the pre-school age children, one group was consisted of children who attend kindergarten (12 examinees), and the other group was consisted of children who do not attend kindergarten (4 examinees). There were twenty girls and boys. According to the place of residence, one group was consisted of children who live in the city center (20 examinees), and the second group was consisted of children who live on the periphery (20 examinees). According to parents' education, one group was consisted of children whose both parents have Bachelor's degree (12 examinees), the second group was consisted of children whose one parent has Bachelor's degree and the other parent has high school diploma (13 examinees) and third group was consisted of children whose both parents have secondary school diploma (15 examinees).

The methods used in the research are following: spontaneous conversation method, descriptive method, a comparative method and a statistical method.

The material was collected by the spontaneous conversation method. In order to lead the examinees to use as much as possible day to day speech or informal speech, a discussion was held on various topics close to examinees. The examiner tried to achieve as much immediacy as possible and to talk to them on the dialect. The examiner starts the conversation, suggests topics, but allows the examinee to talk about different topics in which examinee is interested in. In addition, the examinees responded directly to the questions, if some important detail was not obtained in the spontaneous conversation,

\footnotetext{
${ }^{1}$ In the speech of the children of pre-school and school age, besides the Future I, we followed and investigted the following language variables: the place of accent, the semivowel, the negative form of the auxiliary verb to be in Present, the vowel $h$, the final $l$ in participle, the pronouns with the final $j$ ( $k o j, t o j, n i k o j$ ), enclitical forms of pronouns, the comparison of adjectives, adjective of the verb with the basis of $-n u$, the third person plural in present, noun declension, i.e the use of analytical and synthetic case forms.
} 
they described the drawings with specific instruction of the examiner in the form of questions by which required language feature is obtained. The youngest examinees also described drawings in the drawing books. The most common topics were: kindergarten / school, friends, games, toys, birthday celebrations, winter and summer holidays, trips, excursions, parents, siblings, grandparents, educators, teachers, pets, school activities, free time, hobbies, (cartoons) movies, music, going out, falling in love, learning. The conversation was conducted at least on two occasions. They talked to each examinee individually, in a special room in the kindergarten or school. Only with children who do not attend to kindergarten the conversation was conducted in a home atmosphere, but without the presence of parents. The recorded conversation lasted from one to two hours with each examinee, i.e. two school classes with children of school age. The conversation was recorded with a recorder without the knowledge of the examinees. The descriptive method gives the basic characteristics of the investigated features, analyzes and describes all recorded forms, with reference to the previous dialectological study of Vranje's speech (Barjaktarević, 1965; Belić, 1999) and the neighboring speeches - Pčinja's (Jurišić, 2009), Preševo's and Bujanovac's (Barjaktarević, 1966) and Poljanica's speech (Stevanović, 1969).

The previous researches show that relevant factors for linguistic behavior of children are age, sex, parent language, parents education, type of school they go to, place of residence (Rajić, 2009: 39). That is why we included the following independent variables in the research: age of pupils, sex, education of both parents, place of residence (center / periphery of the city), (no) attendance at kindergarten (going / not going to kindergarten). The tested language feature was statistically processed - the calculated frequency index (IF) of the dialectic forms of Future I is obtained by dividing the number of recorded dialectic forms by the sum of dialectic and standard linguistic forms, and then multiply by 100 (Jutronić-Tihomirović, 1986, 1988-89) i.e. IF indicates the percentage of use of dialectical forms in relation to the sum of standard linguistic and dialectical forms.

$$
I F=\frac{\text { dialectic forms }}{\text { dialectic and standard linguisticforms }} \cdot 100
$$

According to the obtained frequency index value, the use of the dialectic form of futures I is concluded - the higher IF indicates the more frequent use of the dialectic form. The frequency of dialectical forms is related to non-linguistic variables, age, gender, parent education, place of residence, (no) attendance at kindergarten. The comparative method determines the differences in the frequency of the dialectic form of different groups. The obtained results are interpreted by the analysis of the descriptive method and are presented in a table with a comment.

\section{ANALYSIS AND INTERPRETATION OF RESULTS}

Following the forms of the Future I which the examinees used, we established three different future constructions: a standard linguistic future form: the auxiliary verb hteti in the present + infinitive, a future form: the auxiliary verb hteti in present $+\mathrm{da}+$ present and the dialectic future form: će + present.

There are a few examples of the standard linguistic forms in the speech of Vranje's children. Most of the forms of the futures with the inflective auxiliary verb and infinitive the examinees used when they tried to retell a cartoon or a fairy tale, as well as when they 
were given the task to describe the future action shown in the drawings. In the spontaneous speech situation the standard-language forms do not generally exist. The loss of standardlanguage of Future forms with the infinitive involves a wide range of functional styles of the Serbian language (Radić, 2003: 136).

Among the recorded examples there are also simple and complex forms of Future:

1stSG.: biću, biće promocija, voziću, gledaću, kupiću, nacrtaću, piću, pobediću, prepoloviću, sakriću, smisliću, srušiću, staviću, tražiću, ubiću, uništiću, učiću;

2ndSG.: videćeš, moraćeš, popravljaćeš;

3rdSG.: napraviće;

1stPL.: vozićemo, grudvaćemo se i sankati, doručkovaćemo, igraćemo (se), imaćemo, kitićemo, kupaćemo se, kupovaćemo, pričaćemo, radićemo, spavaćemo;

2ndPL.: gledaćete, izgubićete;

3rdPL.: polomiće, pretvoriće se, ubiće;

1stSG.: neću doći, ću se igrati, ići ću;

2ndSG.: / ( there isn't any recorded form);

3rdSG.: će biti, će trebati, će ubiti, će ukrasti;

1stPL.: ćemo se baciti, ići ćemo, ćemo čekati, ćemo učiti;

2ndPL.: / ( there isn't any recorded form);

3rdPL.: će slomiti.

An examinee used the form padnuće, which occured in the desire of using the standard linguistic form.

The confirmation and stabilization of Future form: auxiliary verb hteti in the present $+\mathrm{da}+$ present in the wider range of the Serbian language is the result of a very dynamic process of losing infinitive in the context of linguistic balkanization. This form is in the expansion of spoken and written language in all functional styles (Radić, 2003: 136-137). Among the Serbian grammarians and linguists, the opinion regarding the question of the normative status of this form was divided - whether it should be considered as the standard or the substandard form ${ }^{2}$. In the Normative grammar of the Serbian language (2014) we find the following: „In the forms of complex Future I and the usage of a relation $\mathrm{da}+$ present instead of the infinitive is characteristic of the conversational style and oral informal communication, but on the other occasion the complex future is recommended with the form of infinite and the grammatical element ću, ćeš, će..." (Piper \& Klajn, 2014: 173). Future Tenses, substandard or standard form in spoken Serbian, for sure, is also the dialect form in Serbian language (Radić, 2004: 135-145; Topolinjska, 1994: 149-161), which has influences on the linguistic standard, and at the same time it is expanded under the influence of the language standard.

This form has, in the analyzed speech, replaced the standard-language form:

1stSG.: ću da dođem, ću da donesem, ću da zamislim, ću da idem, ću da imam, ću da jašim, ću da jedem, ću da kažem, ću da kupim, ću da nacrtam, ću da obnovim, ću da obojim, ću da ostanem, ću da pokažem, ću da popravim, ću da pravim, ću da prestanem, ću da se probudim, ću da pročitam, ću da raznesem, ću da rešim, ću da skinem, ću da stavim, ću da ubijem;

2ndSG.: ćeš da budeš, ćeš da glumiš, ćeš da ideš, ćeš da imaš, ćeš da se opametiš, koji ćeš da otvoriš, ćěs da pozoveš;

3rdSG.: će da bude, će da vodi, će da glumi, će da da, će da se desi, će da zaključa, će da zvoni, će da ide, će da ispljune, neće da se istopi, će da može, će da odleti, né́e da se

\footnotetext{
2 More on this issue in Vojvodić 1996: 107-122, Radić 2003: 137, Simić 2009, Okuka 2010.
} 
održi, će da opravda, neće da pada, će da plače, neće da pođe, će da se popravi, će da pobedi, će da pusti, neće da smeta, će da stigne, će da stoji, će da se uda, né́e da se čuje; 1stPL.: ćemo da gledamo, nećemo da diramo, ćemo da završimo, ćemo da zalepimo, ćemo da se izvučemo, ćemo da jedemo, ćemo da kitimo, ćemo da napravimo, ćemo da otkrijemo, ćemo da pevamo, ćemo da počnemo, ćemo da premestimo, ćemo da premeštamo, ćemo da se prepiremo, nećemo da sviramo, ćemo da slušamo, ćemo da treniramo, ćemo da crtamo;

2nd.PL.: ćete da izaberete, ćete da se iznenadite;

3rdPL.: će da budu, će da se vrate, će da daju, će da se klizaju, će da ostanu, će da pevaju, će da porastu, će da počnu da plaćaju, će da spavaju, će da čuče.

Two children used in this form the dialectic form of the third person plural of the present: će da budev, će da kitiv, će da skačev, će da se igrav, će da dav.

Future construction: će + (da) + present is a „Balkan's form“ (Popov, 1984: 40) compared to the previous one - in this analytical form, the auxiliary verb xmemu lost his flexion and became a particle for the future, while the present, as the second part of the form, performs personal pronoun. „The auxalary verb velle gradually disappeared in all the Balkan languages and in most of them came to the extent when it was merely a morphological sign of disability" (Markoviḱ, 1994-1996: 310). This balkanism is peculiar to all the speeches of the PrizrenTimok's spoken zone, and it is also known in Kosovo and Metohija's speeches on the wider territory (Radić, 2004: 137-138).

In the speech of Vranje's children, in most cases, a Future form was used: će + present:

1stSG.: će bijem, će venčavam, će vozim, će vrištim, će gađam, će gledam, će se grudvam, će dobijem, će živim, će zažmurim, ć-idem, će se izgubim, ć-imam, će krenem, će lečim, né́e mogu, će se nasmejem, će odmaram, će odustanem, će se opredeljujem, će peglam, će pišem, će plaćam, će poželim, će promenim, će sednem, će skinem, će skupljam, će slavim, neće slavim, neće spijem, će se trudim, će ustanem, će učim, će čuvam, će šišam;

2ndSG.: će vidišs, će daš, ć-ideš, će nastradaš, će se oduševiš, će ostariš, će se otvoriš, će potoněs, će priča ̌ li, će probiješ, će sedně̌, će se uzbudiš, će umrěs, neće dobiješ;

3rdSG.: će bude, će gura, će dade, će deli, neće dođe, će dopliva, ć-ide, neć-ide, će ima, ćima, će zaleti, će ispituje, će naiđe, će napuni, će omesi, će organizuje, će se otkaže, će pamti, će pozove, će pomisli, će pojede, će predaje, će se preseli, će se razmaže, će reaguje, će samelje, će se sruši, će stane, će uzme, će ujede, će ukljuje, će se uplaši, će se uprlja, će uči, će čuva, će se čudi, će čuka;

1stPL.: će bacamo, će se valjamo, će vidimo, će se vučemo, će glumimo, će doručkujemo, ć-idemo, neće idemo, će idemo li, će imamo, ć-imamo, će jedemo, neće kitimo, će se klizamo, će lečimo, će se menjamo, će operemo, će pevamo, će se penjemo, će plačemo, će pogledamo, će se poigramo, će poludimo, će posadimo, će postavimo, će radimo, će računamo, će svratimo, će se spuštamo, će uđemo, će umažemo, će uništimo, će uhvatimo, će šutiramo;

2ndPL.: neće verujete, će dolazite, ć-idete, će se umorite;

3rdPL.: neće dođev, će budev, će voziv, će idev, ć-idev, neć-idev, će izađev, će iscepiv, će jedev, će kažev, će legav, će se natepav, će obučev, će osvojiv, će spavav, će ručkav, će sečev, će se smejev, će spavav, će pojedev, će porastev, će crtav, će se šetav.

The recorded forms are without a conjunction $d a$. Belić believes that the omitting of the conjunction да in the future tense is recent innovation (Belić, 1999: 411). The four of the types of „,velle-future“ in the speeches of southeastern Serbia, Topolinjska stresses that the type ,ja će da pišem " is the weakest one (Topolinjska, 1994: 152). Periodically participation of the conjunction $\partial a$ is also stated by Radić in Kosovo and Metohija's speeches (Radić, 2004: 139). On the other hand, this conjuction in the futuristic construction can be heard in some 
speeches on the territory of Macedonia, in the Porec-Kicevo's (Koneski, 1966: 173) and Kumanovo speech (Vidoeski, 1962: 221), in contrast to the futuristic structure without the conjunction in the standard Macedonian language. Vidoeski points out the significance of the use of the conjunction $d a$ : „This manner of expression (with $d a$ ) is not unknown in our other dialects. There is, however, a difference in counterfeit speeches in the meaning of that construction. In central and western speeches, for example, it usually expresses a certain assumption in the negative statements and dubiousness. In the northern speeches, and in Kumanovo too, this outline in meaning is not basic. The conjunction can be used without entering in a new important moment" (Vidoeski, 1962: 221). And Koneski explains that the conjunction $\partial a$ is included in a futuristic structure when one assumption is expressed in future time (Koneski, 1981: 488). Otherwise, the conjuction disappeared from these constructions because it did not perform any important differentiating function (Koneski, 1966: 173).

There is only one example with a conjunction that in the second person plural: će da se igramo. Two children used the structure će $+\mathrm{da}+$ present in the third person plural, which makes the difference between the second and third type of Future structure neutral: $c e d a$ budev, će da kitiv, će da skačev, će da se igrav, će da dav. The omitting of the conjunction presents the final stage in the analysis of the future structure (Asenova, 1989: 169).

Other researchers noted in the speech of the Vranje region the usage of this future structure without the conjunction $\partial a$, but also with this conjunction: će pijem, će kradeš, će vikamo, će pecav; će da piješ, će da skitaš, će da berev (Barjaktarević, 1965: 55); će begav, će mi davate, će zna, će prodamo, će rabotamo, će ga razruši; će da vidite, će da skape, će duzne, će da čuvamo (Barjaktarević, 1966: 209); ja će se brinu; ja će da idu (Stevanović, 1969: 418); će sednu, će gi praćam, će ga uzneš, će gu davi, će se kunemo, će liznev; će s konja da idem, što će da rekne (Jurišić 2009: 208-209). Jurišić emphasizes that there are several examples in which the conjunction is omitted (Ibid., 208). The examples from Vranje, which Belić in the Dialects states, are mostly without the conjunction da: će osebneš (169), će vu otkrije veselje (283), nešto će gi pravim (402), će sednemo, će si pominemo, će traživ (407). There is only one example with the conjunction da and the auxiliary verb ću in the first person singular: ja ću da idu (409) (Belić, 1999).

The form with the auxiliary $c u$ in the first person singular, is characteristic with the other speeches of the Prizren-Timok's region (Topolinjska, 1994: 151-152), and also in Vranje as Barjaktarević recorded: ću pričam, ću skačem (Barjaktarević, 1965: 55 ) and Jurišić in Pčinja's speech as well: kako će otidu, ja ли ću ga dignu, i ja ću kažu (Jurišić, 2009: 208). In our material there are no such forms.

In a few examples, in the third person plural with the particularistic auxiliary verb comes the standard language form of a present: će budu, će se drže, će dođu, će se igraju, će idu, će kite, će se klizaju, će kupe, će se ljube, će menjaju, neće mogu da dođu, će naprave, će otvaraju, će pevaju, će pričaju, neće puste, će ručaju, će sagrade, će skaču, će spavaju The form pevaćev is a specific symbiotic form of the first and third type of Future structure: pevaće + će pevav.

In the speech of children of pre-school and primary school age in Vranje, the standard-language future construction is present in a very small number - a total of 67 forms were recorded. On the other hand, 329 forms with the auxiliary verb хтети + да + present and 820 of the dialectic forms će + prezent were used. The frequency index of the dialectic form of Future I is 92.45, which indicates to a high degree of presence of the dialectic Futuristic structure in the speech of Vranje's children. The influence of the standard language on this dialectical feature is almost nonexistent. 
The linguistic expression of children is developing under the influences of different factors- the parents' speech and the closest environment, the mass media, the educators, the teachers and the curriculum in both kindergatren and school.The modern sociolinguistic researches show that age, sex, parents' speech, parents' education, type of school they go to, place of residence are relevant factors for the children's linguistic behavior.The family is the most important factor in the socio-emotional, intellectual and speech development of a child, therefore the modern sociolinguistic researches of the develpoment of the children's speech pay considerable attention to the socio-cultural environment, especially the family.The connection between the socio-economic status of the family and speech development of children was studied by Elizabeth Herlok (1956), Basil Bernstein (1979), Kevin Veldal (1979). Some researchers specifically emphasize differences in speech conditioned by sex women use standard-language forms more widely (Labov 1966, Trudgill 1972, Rajić 1980, Gašić-Pavišić 1981, Savić 1995). Such results of the researches are based on undesrstanding that women are more aware about their positiom in the society. Also, it is expected for the women to act in accordance with established social norms, including the standard language norm. On the other hand,the men use non-standard forms that are pecular for working class because lower-level speech is related to the term masculinity (Petrovic 1999: 64). At preschool age there is no organized learning of the standard language, sothe speech is more spontaneous, more authentic, especially if children do not go to kindergarten. On the other hand, staying in the kindergarten modifies the linguistic expression of children. Educators in the kindergarten are speech models from which the child hears, or should hear the standard language. The school as an educational institution where the language standard is studied, changes the linguistic expression of children. Apart from listening, or should listen, pupils learn the rules of a standard language, so the school should have a greater impact on their speech than the kindergarten. Regarding the place of residence, the cultural identity of the city center - theater, cinema, schools, sports center, park, cafes, provides more favorable conditions for the development of linguistic expression in relation to the rural periphery of the city. In accordance with the mentioned observations, in this part of the paper we wanted to determine how much the frequency of the usage of the Futur ce-structure is conditioned by the specified non-linguistic factors.

The frequency index of the usage of the dialectic future form in relation to age, gender, education of parents, place of residence, (non)attendance at kindergarten and attendance at kindergarten/school is given in Table 1.

Table 1 The index of frequency of the usage of the dialectic future form in relation to non-linguistic factor

\begin{tabular}{ll}
\hline Non-lingustic variables & IF \\
\hline Age & \\
Pre-school & 95,34 \\
School 1-4 & 73,76 \\
School 5-8 & 97,61 \\
\hline Sex & \\
Male & 92 \\
Female & 92,91 \\
\hline Parents' education & \\
Bachelor's Degree & 78,68 \\
Bachelor's Degree/High school diploma & 92,60 \\
High school diploma & 99,47 \\
\hline Place of residence & \\
Center & 89,96 \\
Periphery & 95,10 \\
\hline Kindergarten & \\
attendance & 93,73 \\
No attedance & 100 \\
\hline Kindergarten/School & \\
Attend kindergarten & 93,73 \\
Attend school & 88 \\
\hline
\end{tabular}

The analysis of the results was done for each independent variable. 
As for the age, the frequency of the dialectic form of future in the speech of preschool children (IF = 95.34) and children of school age from the fifth to the eighth grade is almost equal $(\mathrm{IF}=97,61)$. On the other hand, children of school age from the first to the fourth grade use less dialectic form (IF = 73.76). Analyzing IF of all three age groups, we note that age does not affect the frequency of usage of the dialectic futures forms - with age the frequency does not decrease.

The statistical data show that sex has no influence on the usage of the dialectic futures forms - both boys (IF = 92) and girls (IF = 92.91) are equally using the dialectic futures form.

The lowest frequency index of the dialectic futures forms is the speech of children where both parents are with the bachelor's degree (IF $=78.68$ ). With a lower degree of education, the frequency of the dialectic futures forms increases - in the second educational group IF is higher (IF = 92.60), and in the third it is the highest (IF =99.47). The difference between the second and the third groups is not large. Therefore, the education of parents has influence on the usage of dialectic futures forms.

When it comes to the place of residence, the analysis shows that children from the periphery use somewhat more of the dialectic future forms - (IF $=95.10)$ compared to children from the center ( $I F=89.96)$. The influence of the place of residence on the usage of the dialectic future forms is visible, but not too great.

It is not a big difference in the frequency of the dialectic future forms nor when it comes to the (non) attendance of a kindergarten - a slightly lower frequency index has the speech of children who go to kindergarten (IF = 93.73), while children who do not go to kindergarten have never used the standard form (IF = 100). So, the influence of the kindergarten is not great.

The difference in the frequency of the dialectic future forms between children who go to kindergarten $(\mathrm{IF}=93.73)$ and children who go to school $(\mathrm{IF}=88)$ exists, but it is not large. Based on statistical data, we note that, although the linguistic standard is taught in school, this institution does not contribute significantly to the usage of the standardlanguage future forms.

\section{CONCLUSIONS}

Futur I in the speech of Vranje's children of pre-school and primary school age appears in three different forms: in the form of standard-language future constructions: an auxiliary verb hteti in present + infinitive (voziću, videćeš, napraviće, radićemo, izgubićete, pretvoriće se; ići ću, će biti, ćemo se baciti, će slomiti), in the form of the future construction: auxiliary verb хтети in present $+\mathrm{da}+$ present (ću da dođem, ćeš da glumiš, će da zvoni, ćemo da otkrijemo, ćete da izaberete, će da se vrate) and the form of the dialectic future structure: će + present (će venčavam, će vidiš, će napuni, će bacamo, će dolazite, će obučev).

In the usage of these three variable forms, the lowest frequency shows the standard linguistic construction (67 recorded forms), then the construction with auxiliary verb hteti $+\mathrm{da}+$ present $(329$ recorded forms). The dialectic $\hbar e$-structure is the most frequent $(820$ recorded forms with the frequency index of 92.45), which tells about the great stability of this dialectic feature and the weak influence of the standard language on it.

By calculating the frequency index of dialectic Future I forms and according to nonlinguistic variables - age of pupils, sex, education of both parents, places of residence, attendance at kindergarten/school, we see that non-linguistic factors have an influence on 
the usage of future $c e$-construction, except for their age and sex. However, this influence is not great - differences in IF are small.

The results we obtained in this research are important for the organization of the teaching process in teaching of Future I. The standard linguistic form of The Future I is more difficult to adopt, so to this form of analysis the special attention should be paid, to access it in a special way from the very beginning of work with students, with an increased number of exercises. Since the dialect forms of this feature are very frequent, it is exactly the staring point with the adoption of standard linguistic forms. According to the principle of homeliness, a correlation between dialectical and standard linguistic forms is established.This comparative approach is in line with the principles of differential grammar and didactic requirements, it means that in teching we should start from close to further, from the known to the unknown (Marinković, Tomić, Prvulović 2010: 305). In this way, the child's speech is respected, whereby it is motivated to express freely, without fear of making mistakes in standard language norms.

The successful adoption of the standard linguistic of The Future I forms can also contribute to a greater number of speech exercises, aimed precisely at practicing this feature, and in higher grades of primary school and work in the linguistic section and language analysis of literary works written on the dialect. Since at the pre-school level there are no organized classes of the Serbian language, the adoption of standard-language The Future I forms should be based on well-organized speech exercises and constant, upand-coming and unobtrusive correction of the dialect form in children's speech. Finally, the educators and the teachers themselves are speech models, so they should take care of every spoken word, know and respect the standard language norm in their speech, and thus nurture the standard linguistic expression.

\section{REFERENCES}

Asenova, P. (1989). Balkansko ezikoznanie. Osnovni problemi na balkanskià ezikov sãäz [Balkan linguistics. The Basic Problems of the Balkan Language Alliance]. Sofià: Izdatelstvo nauka i izkustva.

Barjaktarević, D. (1965). Fonetske i morfološke osobine vranjskog govora [Phonetic and Morphological Characteristics of Vranje Speech]. Vranjski glasnik [Vranje's messenger], I, 33-58.

Barjaktarević, D. (1966). Preševsko-bujanovačka govorna zona [Presevo-Bujanovac Speech Zone]. Vranjski glasnik [Vranje's messenger], II, 173-218.

Belić, A. (1999). Dijalekti istočne i južne Srbije [Dialects of Eastern and Southern Serbia]. Beograd: Zavod za udžbenike i nastavna sredstva.

Bošnjaković, Ž. (2009). Odnos standardnih i dijalekatskih osobina u govoru učenika nekih banatskih osnovnih škola [Relation of Standard and Dialectic Characteristics in the Speech of Pupils of Some Banat Elementary Schools]. Naučni sastanak slavista u Vukove dane [The Scientific Meeting of the Slavists in the Vuk's Day], XXXVIII(1), 341-350.

Ćupić, D. (2001). Nastava jezika i dijalekat [Language Teaching and Dialect]. Zbornik Instituta za pedagoška istraživanja [Anthology of the Institute for Pedagogical Research], XXX(3), 346-350.

Dešić, M. (1981). Uloga lokalnog govora u razvijanju govorne kulture učenika [The role of local speech in development the pupils'speech culture]. Naš jezik [Our Language], XXV(3), 162-166.

Gašić-Pavišić, S. (1981). Slobodne asocijacije reči kod dece: karakteristike i pedagoške implikacije. Beograd: Institut za pedagoška istraživanja / Prosveta.

Herlok, E. (1956). Razvoj deteta [Child Development]. Beograd: Zavod za izdavanje udžbenika Socijalističke Republike Srbije / Beograd: Beogradski grafički zavod.

Janjić, M. (2004). Nastava padeža u osnovnim školama prizrensko-timočkog dijalekta [The teaching of declination forms in elementary schools of Prizren-Timok dialect]. Književnost $i$ jezik [Literature and language], LI(3-4), 407-425. 
Janjić, M. (2005a). Nastava padeža u teoriji i praksi [The teaching of declination forms in theory and practice]. Vranje: Učiteljski fakultet (Vranje: Aurora).

Janjić, M. (2005b). Neki problemi u vezi sa nastavnim interpretacijama akuzativa i lokativa u osnovnim školama na dijalekatskom području [Some problems related to teaching interpretations of accusative and locative in primary schools in the dialect area]. Srpski jezik [Serbian language], X(1-2), 629-637.

Janjić, M. (2011). Govor mladih Vranjanaca: od dijalektizma do anglicizma [Speech by young Vranjans: from Dialectism to Anglicism]. Naše stvaranje [Our creation], LVIII(1-4), 109-115.

Janjić, M. (2016). Afektivne strategije u nastavi akcenata na području prizrensko-timočkog dijalekta [Afective strategies in teaching accents in the area of Prizren-Timočki dialect]. U R. Žugić (Ur.) Naučni skup: Dijalekti srpskog jezika: istraživanja, nastava, književnost [Scientific Meeting: Dialects of the Serbian language: research, teaching, literature] (str.369-381). Leskovac: Leskovački kulturni centar, Vranje: Univerzitet u Nišu, Pedagoški fakultet u Vranju.

Jerković, J. (1992). Srpski govor Bečeja [Serbian speech Becej]. Zbornik Matice srpske za filologiju i lingvistiku [Anthology of the Matica Srpska for Philology and Linguistics], XXXV(2), 89-98.

Jović, D. (1976). Jezik urbanih sredina [Language of urban environments]. Gledišta [Views], XVII(7-8), 732-744.

Jović, D. (1979). Sociolingvistički faktori jezičkih promena u župskom govoru [Sociolinguistic factors of language changes in Župa speech]. Književnost i jezik [Literature and Language], XXVI(2-3), 243-251.

Jurišić, M. (2009). Govor Gornje Pčinje: glasovi i oblici [Speech by Gornja Pčinja: Phones and Forms]. Beograd: Institut za srpski jezik SANU.

Jutronić-Tihomirović, D. (1986). Morfološke promjene u splitskom vernakularu [Morphological changes in the Split Vernacular]. Filologija [Philology], XIV, 153-160.

Jutronić-Tihomirović, D. (1988-1989). Jezično prilagođavanje na sintaksičkom nivou [Language adjustment at a syntax level]. Radovi Filozofskog fakulteta u Zadru. Razdio filoloških znanosti [Papers of the Faculty of Philosophy in Zadar, Section of Philological Sciences], XVIII, 1-60.

Koneski, B. (1966). Istorija makedonskog jezika [History of the Macedonian Language]. Beograd: Prosveta, Skopje: Kočo Racin.

Koneski, B. (1981). Gramatika na makedonskiot literaturen jazik [Grammar of the Macedonian Literary Language]. Skopje: Kultura.

Kristal, D. (1987). Kembrička enciklopedija jezika [Kembrick encyclopedia of language]. Beograd: Nolit.

Labov, W. (1966). The Social Stratification of English in New York City. Washington: Center for Applied Linguistics.

Labov, W. (1976). Sociolinguistic patterns. Philadelphia: University of Pennsylvania Press.

Marinković, J., Janjić, J. (2009). Diferencijalna gramatika: srpski jezik i prizrensko-timočki govorni prostor [Differential grammar: Serbian Language and Prizren-Timočki Speaking Area]. Vranje: Učiteljski fakultet (Vranje: Aurora).

Marinković, J., Prvulović, B. Tomić, D. (2010). Diferencijalna gramatika, Inovativni pristup u nastavi maternjeg jezika na dijalekatskom jezičkom području [Differential grammar, An innovative approach to teaching mother tongue in a dialectical language area]. Godišnjak Učiteljskog fakulteta u Vranju [Annual of Teacher Training Faculty in Vranje], 1, str. 305-313.

Markoviḱ, M. (1994-1996). Način na izrazuvanje na idnost vo makedonskiot i vo aromanskiot ohridski govor [The way of expressing the future in the Macedonian and Aromanian ohrid speech]. Makedonski jazik [Macedonian language], LXV-LXVII, 309-316.

Marković, J. (2012). Jezik dece predškolskog uzrasta između standarda i dijalekta [The language of pre-school age children between the standard and the dialect]. U M. Kovačević (Ur.) Naučni skup: Srpski jezik, književnost, umetnost. Knjiga I, Strukturne karakteristike srpskog jezika [Scientific Meeting: Serbian language, literature, art. Book I, Structural characteristics of the Serbian language] (str. 245-251). Kragujevac: Filološko-umetnički fakultet.

Mihajlović, J. (2008). Standardni srpski jezik učenika osnovnih škola u Sirinićkoj župi [Standard Serbian language elementary school students in Sirinićka župa]. Istraživanje srpskog jezika na KiM [Serbian language research on Kosovo and Metohija], I, 189-204.

Moskovljević, M. (1921). Nekoliko reči o beogradskom govoru [A few words about Belgrade's speech]. U Zbornik Filoloških i lingvističkih studija: Aleksandru Beliću povodom 25-godišnjice njegova naučna rada posvećuju njegovi prijatelji i učenici [Anthology of Philological and linguistic studies: Aleksandar Belić on the occasion 25anniversary his scientific work dedicate his friends and students] (str. 132-149). Beograd: S. B. Cvijanović.

Nikolić, B. (1956). Korišćenje dijalekatskih pojedinosti u nastavi našeg jezika [Using dialectical details in our language teaching]. Književnost i jezik [Literature and language], VIII-IX, 490-492.

Nikolić, V. (1998). Uloga jezičkog osećanja i jezika sredine u poimanju strukture jezika i meta jezika gramatike [The role of linguistic feeling and the language of the environment in understanding the structure of the language and meta- language grammar]. Školski čas [School class], XIV(1-2), 65-79. 
Okuka, M. (2010). Nemoj da odeš, Srbija će da plače. Urušavanje ili obnavljanje sistema književnog jezika? [Do not go, Serbia will cry. Crashing or restoring the literary language system?] Interdisciplinarnosti $i$ jedinstvo savremene nauke [Interdisciplinarity and unity of contemporary science], IV(1), 7-30.

Petrović, A. (1999). Jezičke osobine učenika u školama srednjeg obrazovanja [Language features of pupils in secondary schools]. Doktorska disertacija [Doctoral dissertation]. Filološki fakultet. Beograd.

Piper, P., Klajn, I. (2014). Normativna gramatika srpskog jezika [Normative grammar of the Serbian language]. Novi Sad: Matica srpska.

Popov, B. (1984). Položaj srpskohrvatskog jezika u balkanskom jezičkom savezu [The position of the Serbo-Croatian language in the Balkan Language alliance]. Južnoslovenski filolog [South Slavic philologist], LX, 21-43.

Radić, P. (2003). O dva aspekta balkanizacije srpskog književnog jezika [About two aspects of balkanization of the Serbian literary language]. Južnoslovenski filolog [South Slavic philologist], LIX, 105-152.

Radić, P. (2004). Glagolske će-konstrukcije u govorima Kosova i Metohije. Balkanistički aspekt [Verb ćeconstruction in the speeches of Kosovo and Metohija]. Južnoslovenski filolog [South Slavic philologist], LX, 135-145.

Radić, P. (2008). Dijalekat i norma u nastavi srpskog jezika [The dialect and the norm in the teaching of the Serbian language]. Književnost i jezik [Literature and language], XL(1-2), 127-140.

Rajić, Lj. (1980). Jezik i identitet - položaj korisnika dijalekta u procesu standardizacije govora [Language and identity- the position of the dialect user in the speech standardization process]. Godišnjak Saveza društava za primenjenu lingvistiku Jugoslavije [An annual association of societeies for applied linguistics of Yugoslavia], IV-V, 373-376.

Rajić, Lj. (2009). Gradski govori [City speeches]. U Ž. Bošnjaković (Ur.), Govor Novog Sada. Sveska 1: Fonetske osobine [Speech of Novi Sad: Phonetic characteristics] (str. 31-45). Novi Sad: Filozofski fakultet, Odsek za srpski jezik i lingvistiku.

Savić, S. (1995). Jezik i pol (I) Istraživanja u svetu [Language end sex I Research in the world]. Ženske studije [Women's studies], I, 197-209.

Savić, S. (1999). Osnovni principi deskripcije i selekcije razgovornog jezika: korpus lingvistika [Basic principles of description and selection of the spoken language: corpus linguistics]. U Plankoš J. (Уp.) Naučni skup: Aktuelni problemi gramatike srpskog jezika [Scientific Meeting: Current problems of grammar of the Serbian language] (стр. 89-95). Subotica-Beograd: Gradska biblioteka.

Simić, R. (2009). Normativni i upotrebni status futuroida ĆU, ĆEŠ...+ DA + PREZENT [Normative and usable status of futuroids ĆU, ĆEŠ́...+ DA + PREZENT]. Naučni sastanak slavista u Vukove dane [Scientific meeting of Slavs in Vuk's days], XXXVIII(1), 51-55.

Smiljković, S., Žugić, R., Stojanović, S. (2009). Nastava srpskog jezika na dijalekatskom području [Teaching Serbian language in the dialect area]. Vranje: Učiteljski fakultet.

Stevanović, V. (1969). Govor Poljanice [Speech of Poljanica]. Vranjski glasnik [Vranje's messenger], V, $399-422$.

Topolinjska, Z. (1994). Infinitiv vs da-subjunktiv u formuli velle-futura [Infinitive vs da-subjunctive in velle-futura formula]. U P. Ivić i dr. (Redakc. odbor) Naučni skup: Govori prizrensko-timočke oblasti $i$ susednih dijalekata [Scientific Meeting: Speeches of the Prizren-Timoc region and the neighboring dialects] (str. 149-160). Beograd: Institut za srpski jezik SANU. Niš: Centar za naučna istraživanja SANU i Univerziteta u Nišu.

Trudgill, P. (1972). Sex, covert prestige and linguistic change in the urban British English of Norwich. Language in Society, I, 179-195.

Veldal, K. (1979). Društveno ponašanje [Social behavior]. Beograd: Nolit.

Vidoeski, B. (1962). Kumanovskiot govor [Kumanovo speech]. Skopje: Institut za makedonski jazik.

Vojvodić, D. (1996). Status futura I u književnoumjetničkom i publicističkom stilu [The status of Future I in the literary and public style]. Južnoslovenski filolog [South Slavic philologist], LII, 107-122.

Vrećić, D. (1975). Prevencija i korekcija lokalizama u govoru učenika osnovne škole [Prevention and correction of localisms in the speech of elementary school pupils]. Pedagoška stvarnost [Pedagogical reality], XXI(9), 544-549.

Vrećić, D. (1977). Osnovna škola i problemi lokalnog govora u nastavi srpskohrvatskog jezika [Elementary school and problems of local speech in the teaching of the Serbo-Croatian language]. Pedagoška stvarnost [Pedagogical reality], XXIII(5), 365-376.

Žugić, R. (2013). Upotreba padeža u pisanom izražavanju studenata na području prizrensko-timočkog dijalekta [The use of declination forms in the written expression of students in the area of Prizren-Timok dialect]. Zbornik radova Filozofskog fakulteta u Prištini [Anthology papers of Faculty of Philosophy in Priština], XLIII(2), 511-528. 


\section{FUTUR I U GOVORU VRANJSKE DECE PREDŠKOLSKOG I OSNOVNOŠKOLSKOG UZRASTA}

U radu su predstavljeni rezultati analize upotrebe futura I u govoru vranjske dece predškolskog $i$ osnovnoškolskog uzrasta. U vezi s tim, navedeni su svi oblici futura I koje ispitanici koriste, a zatim je izračunavanjem indeksa frekvencije (IF) utvrđena frekvencija upotrebe dijalekatske futurske konstrukcije $i$ zavisnost upotrebe ove konstrukcije od nejezičkih činilaca - uzrasta učenika, pola, obrazovanja oba roditelja, mesta stanovanja, pohađanja vrtića/škole. Uzorkom je obuhvaćeno 40 ispitanika, dece predškolskog $i$ osnovnoškolskog uzrasta, različitog pola, obrazovanja roditelja $i$ mesta stanovanja. Dobijeni rezultati ukazuju na korišćenje tri različite konstrukcije u službi futura I, pri čemu je dijalekatska futurska će-konstrukcija najfrekventnija i otporna na uticaj jezičkog standarda. Takođe, uticaj nejezičkih činilaca na upotrebu dijalekatskog futurskog oblika je vidljiv, ali ne veliki. Pritom, uzrast i pol nemaju uticaja. Dobijeni rezultati mogu doprineti poboljšanju obrade futura I u nastavi srpskog jezika, što je od posebnog značaja za nastavu na izrazitom dijalekatskom području kakvo je prizrensko-južnomoravsko područje, kome pripada vranjski govor.

Ključne reči: govor dece, futur I, frekvencija, nejezički činioci. 